\title{
Biological reactions of forests to climate change and air pollution
}

\author{
Rainer Matyssek · Alessandra R. Kozovits • \\ Gerhard Wieser · Ingrida Augustaitiene • \\ Algirdas Augustaitis
}

Published online: 16 April 2014

(c) Springer-Verlag Berlin Heidelberg 2014

From May 18 through 26, 2012, the conference on "Biological Reactions of Forests to Climate Change and Air Pollution" was held in Kaunas/Lithuania under the auspices of the International Union of Forest Research Organizations (IUFRO), represented by the Working Group 7.01.00 (chaired by Andrzej Bytnerowicz and Elena Paoletti) on "Impacts of Air Pollution and Climate Change on Forest Ecosystems." Local organizers were Algirdas Augustaitis and Ingrida Augustaitiene from the Aleksandras Stulginskis University. More than 200 scientists from 34 countries gathered at the University Campus to share the current state of knowledge and discuss scientific gaps in the understanding of the concerted action of climate change and air pollution on forest ecosystems and their responsiveness (Augustaitis et al. 2014). A number of publications were selected for this Special Topic, which originated from presentations relating to "Mechanisms of Action and Indicator Development"-being the title of one of the sessions and also of Research Group 7.01.02 chaired by the three first authors of this editorial. In the following, an

R. Matyssek ( $\square)$

Ecophysiology of Plants, Technische Universität München, Freising, Weihenstephan, Germany

e-mail: matyssek@wzw.tum.de

\section{A. R. Kozovits}

Instituto de Cièncias Exatas e Biológicas, Universidade Federal de Ouro Preto, Ouro Preto, Brazil

\section{G. Wieser}

Federal Office and Research Centre for Forests, Alpine

Timberline Ecophysiology, Innsbruck, Austria

I. Augustaitiene $\cdot$ A. Augustaitis

Laboratory of Forest Monitoring, Aleksandras Stulginskis

University, Akademija, Kaunas, Lithuania overview will briefly be presented on the scope of the conference and the focus of the selected publications.

The long-standing commitment of IUFRO Working Group 7.01.00 is to foster international cooperation between scientists, policy makers and governmental institutions based on conferences that are to share the current state of knowledge on climate change and air pollution effects on forest trees and ecosystems. This implies clarification of underlying mechanisms and harmonization of strategies for risk mitigation. Air pollution has attained attention as a stress component which is intrinsically woven with the phenomena of climate and global change, recognizing extensive forest burning, in particular, as a means of land-use change (Matyssek et al. 2014). On such grounds, the need and significance at the forest tree and ecosystem scale have become evident for long-term ecological research on the main challenge in understanding, which is the process-based, cause-effect-related clarification of system responsiveness to a changing and polluted environment, comprising capacities for risk mitigation through mechanisms of stress acclimation and adaptation. This challenge requires the exploration of scenarios that integrate biotic interactions, e.g., such of competition and diseases as well as belowground agents as modifiers of climate change and air pollution effects. Indispensible, in addition, is the initiation of comprehensive systems biology that needs to extend beyond the molecular level of metabolic control toward the integration of the (eco-)physiological process level. This means that an "ecosystems biology" is required for establishing mechanistic understanding of nonlinearities and emergent synergies in system behavior (Matyssek et al. 2012a). It was concluded that at the present stage, the step needs to be taken from filling gaps in evidence toward reaching integration of knowledge across spatio-temporal scales. 
For mastering the outlined research challenge, it was found to be imperative to re-organize ecological long-term research into a network of intensely instrumented "supersites" allowing for mechanistic forest ecosystem research across spatio-temporal scales (Fischer et al. 2011). This concept has been propagated recently by the EU-funded COST Action FP0903 ("Climate Change and Forest Mitigation and Adaptation in a Polluted Environment" (MAFor; http://cost-fp0903.ipp.cnr.it; Paoletti and Tuovinen 2011), which has closely collaborated scientifically with the IUFRO Working Group 7.01.00. The supersite research is to meet the joint aims by reconciling process-oriented analysis, long-term monitoring and numeric modeling while integrating soil, plant and atmospheric sciences in accounting for climatically extreme years as well as past and present management practices. As an outcome, quantitative knowledge on the effects of silvicultural treatments is envisaged on the carbon, nutrient and water budgets of ecosystems and on pollution and climate-related risks. A scientifically sound stage will be provided for political decision-making toward enhancing the reliability and effectiveness of management strategies and practices, and for strengthening the link between researchers and end users of elaborated knowledge. Recent reviews have highlighted the currently most demanding research needs within the scopes of the IUFRO conference and MAFor as well as the capacities "supersites" may evolve in tackling the associated challenges (Matyssek et al. 2012b, 2013).

The publications selected for this Special Topic relate to the conceptual outline accentuated above as specified in the following. Baumgarten et al. (2014, this vol.) evaluate targeting of forest transpiration through empirical sap flow assessment versus hydrological modeling by making use of datasets on adult Fagus sylvatica from eight forest sites across Bavaria, Germany. Confirming generic allometric principles of trees as a basis for stand-level up-scaling of transpiration, agreement was largely demonstrated between the two approaches, although modeling tended to overestimation at low soil moisture. Stand-level hydrological modeling is promoted through demonstrating the need for covering stomatal regulation during temporary water limitation. The aspect of forest water relations is extended by Leo et al. (2014, this vol.) to inner-alpine coniferous stands in Tyrol, Austria, composed of Pinus sylvestris in association with Picea abies and Larix decidua. Employing a rain exclusion approach, Pinus sylvestris and Picea abies pursue "isohydric" behavior in closing their stomata under incipient drought, which enables early stabilization in water relations. Larix decidua contrasts by "anisohydric" strategy, maintaining high transpiration rates under progressive drought, perhaps being facilitated by the reduced soil water consumption of the other two tree species. A multivariate analysis of ionic composition of rainfall is presented by Caggiano et al. (2014, this vol.) for mountainous ecosystems dominated by Fagus sylvatica or Picea abies in the Western Balkans of Bulgaria. As bulk precipitation ranges around $\mathrm{pH}$ of $5.1, \mathrm{Ca}^{2+}$ and $\mathrm{NH}^{4+}$ represent the dominant neutralization agents, with $\mathrm{Ca}^{2+}, \mathrm{K}^{+}$, $\mathrm{Mg}^{2+}, \mathrm{Cl}^{-}$and $\mathrm{SO}_{4}{ }^{2-}$ originating from anthropogenic rather than natural sources. Dry deposition on foliage is substantial in both ecosystem types, although being outweighed by canopy leaching in Picea abies, in particular regarding $\mathrm{Ca}^{2+}$. Latter forests were conspicuous also in terms of $\mathrm{N}$ uptake and $\mathrm{K}^{+}$and $\mathrm{Mg}^{2+}$ leaching. The reported ionic relationships mediate to Juknys et al. (2014, this vol.), elucidating stages in growth response of Pinus sylvestris trees in Lithuania upon changing pollution by a fertilizer producing facility. Initial stages of stimulation under high $\mathrm{N}$ deposition developed into growth depression, although reduction in emissions enabled recovery to individually variable extents, even in cases of severe damage. Crown defoliation proved as a reliable predictor of tree recovery, being favored by reduced competition at low stand density.

Enhanced $\mathrm{CO}_{2}$ supply as another aspect of air pollution may interfere with the plants' ability of parasite defense. This is explored by Watanabe et al. (2014, this vol.) through a free-air $\mathrm{CO}_{2}$ enrichment study in Japan on Quercus mongolica var. crispula coppice forests as attacked by powdery mildew (Erysiphe alphitoides). Growth of re-sprouting plants was enhanced under elevated $\mathrm{CO}_{2}$, which conversely reduced infection in leaves of both the spring flush and lammas shoots. While enhancing the net photosynthetic rate in re-sprouting plants, enhancement was not found before coppicing. However, photosynthesis was reduced by severe infection on lammas shoots of resprouting plants under unchanged ambient $\mathrm{CO}_{2}$ conditions. How to harden plants against air pollutants ? This issue is exemplified by Katanic et al. (2014, this vol.), treating an $\mathrm{O}_{3}$-sensitive poplar clone with the anti-oxidant ethylenediurea under field conditions, with focus on resulting belowground effects on mycorrhizae. Plants protected by the anti-oxidant showed enhanced total number of fine roots, of ectomycorrhizal differentiation, and increases in the Shannon-Weaver diversity and species richness indices. Shifts occurred in mycorrhizae from contact to shortdistance exploration type in treated trees. Excessive forest burning contributes to climate change through abundant $\mathrm{CO}_{2}$ and air pollutant release, e.g., of precursors of tropospheric $\mathrm{O}_{3}$ formation. Keeping focus belowground, Motiejunaite et al. (2014, this. vol.) explored effects of crown and surface fire in Pinus mugo and Pinus sylvestris stands, respectively, in the coastal sand dunes of the $\mathrm{Cu}$ ronian Spit in Lithuania on early fungal community succession. Upon fire, numbers of fungal species, although fluctuating, increased yearly, while species composition 
qualitatively differed from that of control sites in both tree species. The chronosequence of mycobiota upon surface fire was less defined than upon crown fire, although early post-fire fungal succession ended after 3 years, regardless of fire type. Principe et al. (2014, this. vol.) stress that especially in semi-arid areas like in Portugal with land degradation and desertification risks, natural forest regeneration is slow and hardly studied upon agricultural abandonment. A model is presented for prediction of natural regeneration success, exemplifying Quercus ilex woodlands by making use of long-term time series of aerial photographs and (micro-)climatic databases. Regeneration is shown to succeed with increasing light exposure. The modeling tool may encourage reforestation at favorable sites and identify additional ones conducive to the initiation of natural regeneration processes.

It is concluded from the presentations during the conference and the paper selection introduced above that the critical mass of research teams and promisingly diversified expertise exist within the international scientific community to get a network of "supersites" for forest research (see above) operational at trans and intercontinental scales.

\section{References}

Augustaitis A, Bytnerowicz A, Paoletti E (2014) Biological reactions of forests to climate change and air pollution. Environ Pollut 184:657-658

Baumgarten M, Weis W, Kühn A, May K, Matyssek R (2014) Forest transpiration-targeted through xylem sap flow assessment versus hydrological modeling. Eur J For Res. doi:10.1007/ s10342-014-0796-4

Caggiano RMD, Fikova R, Trippetta S, Bratanova-Doncheva S, Ignatova N, Telesca L (2014) An assessment of rainfall modification in mountainous ecosystems dominated by Fagus sylvatica L. and Picea abies (L.) Karst. (Western Balkans, Bulgaria) by multivariate analyses. Eur J For Res. doi:10.1007/ s10342-013-0713-2

Fischer R, Aas W, De Vries W, Clarke N, Cudlin P, Leaver D, Lundin L, Matteucci G, Matyssek R, Mikkelsen TN, Mirtl M, Öztürk Y, Papale D, Potocic N, Simpson D, Tuovinen J-P, Vesala T, Wieser G, Paoletti E (2011) Towards a transnational system of supersites for forest monitoring and research in Europe-an overview on present state and future recommendations. iForest iForest-Biogeosci For 4:167-171

Juknys R, Augustaitis A, Vencloviene J, Kliučius A, Vitas A, Bartkevičius E, Jurkonis N (2014) Dynamic response of tree growth to changing environmental pollution. Eur J For Res. doi:10.1007/s10342-013-0712-3

Katanić M, Paoletti E, Orlović S, Grebenc T, Kraigher H (2014) Mycorrhizal status of an ozone- sensitive poplar clone treated with the anti-ozonant ethylenediurea. Eur J For Res (this. vol.)

Leo M, Oberhuber W, Schuster R, Grams T, Matyssek R, Wieser G (2014) Evaluating the effect of plant water availability on inneralpine coniferous trees based on sap flow measurements. Eur J For Res. doi:10.1007/s10342-013-0697-y

Matyssek R, Gayler S, zu Castell W, Oßwald W, Ernst D, Pretzsch H, Schnyder H, Munch JC (2012a) Predictability of plant resource allocation: new theory needed? In: Matyssek R, Schnyder H, Osswald W, Ernst D, Munch JC, Pretzsch H (eds) Growth and defence in plants-resource allocation at multiple scales Ecological Studies, vol 220. Springer, New York, pp 433-449

Matyssek R, Wieser G, Calfapietra C, de Vries W, Dizengremel P, Ernst D, Jolivet Y, Mikkelsen TN, Mohren GMJ, le Thiec D, Tuovinen J-P, Weatherall A, Paoletti E (2012b) Forests under climate change and air pollution: gaps in understanding and future directions for research. Environ Pollut 160:57-65

Matyssek R, Clarke N, Cudlin P, Mikkelsen TN, Tuovinen J-P, Wieser G, Paoletti E (eds) (2013) Climate change, air pollution and global challenges: understanding and perspectives from forest research. Developments in Environmental Science 13, Elsevier, Amsterdam, p 622

Matyssek R, Kozovits AR, Schnitzler J, Pretzsch H, Dieler J, Wieser $\mathrm{G}$ (2014) Forest trees under air pollution as a factor of climate change. In: Tausz $\mathrm{M}$, Grulke $\mathrm{N}$ (eds) Trees in a changing environment: ecophysiology, adaptation and future survival. Springer, New York

Motiejunaite J, Adamonyte G, Irsenaite R, Juzenas S, Kasparavicius J, Kutorga E, Markovskaja S (2014) Early fungal community succession following crown fire in Pinus mugo stands and surface fire in Pinus sylvestris stands. Eur J For Res. doi:10. 1007/s10342-013-0738-6

Paoletti E, Tuovinen J-P (2011) COST action FP0903: research, monitoring and modelling in the study of climate change and air pollution impacts on forest ecosystems. iForest-Biogeosci For 4:160-161

Principe AS, Nunes A, Pinho P, Rosario L, Correia Otilia, Branquinho C (2014) Modeling the long-term natural regeneration potential of woodlands in semi-arid regions to guide restoration efforts. Eur J For Res. doi:10.1007/s10342-014-0787-5

Watanabe M, Kitaoka S. Norikazu E, Watanabe Y, Satomura T, Takagi K, Satoh F, Koike T (2014) Photosynthetic traits and growth of Quercus mongolica var. crispula sprouts attacked by powdery mildew under free air $\mathrm{CO}_{2}$ enrichment. Eur J For Res. doi:10.1007/s10342-013-0744-8 